\title{
Biochar and its impact on soil properties, growth and yield of okra plants
}

Diego Bispo dos Santos Farias ${ }^{1}$, Maria Iderlane de Freitas ${ }^{2}$, Ariovaldo Antonio Tadeu Lucas ${ }^{3}$, Maria Isidória Silva Gonzaga ${ }^{3}$

${ }^{1}$ Universidade Federal de Viçosa - UFV, MG. ${ }^{2}$ Universidade Federal Rural de Pernambuco - UFRPE, PE. ${ }^{3}$ Universidade Federal de Sergipe - UFS, SE. E-mail: diego.farias@ufv.br

\begin{abstract}
Applying biochar to the soil can mitigate problems that hinder agricultural production, such as water scarcity and low fertility soils. The objective of this research was to evaluate the impact of dry coconut husk biochar and sewage sludge combinations on soil chemical characteristics, growth, yield and water productivity of okra crop. The experiment was arranged in randomized blocks, with 6 treatments $(\mathrm{CHB}+$ BSS - coconut husk biochar + biochar of sewage sludge, CHB + RSS - coconut husk biochar + raw sewage sludge, BSS + RSS - biochar of sewage sludge + raw sewage sludge, CHB - coconut husk biochar, BSS biochar of sewage sludge, WB - without biochar (control)). Plant height, number of fruits per plant, yield and water use productivity were evaluated. To evaluate the effect of biochar on soil, soil samples were taken to determine $\mathrm{pH}, \mathrm{CEC}, \mathrm{P}, \mathrm{K}, \mathrm{Ca}, \mathrm{Mg}$ concentrations after incorporation of biochar into the soil. The BSS + RSS and BSS treatments provided better results on okra production and growth characteristics with a $421.15 \%$ and $419 \%$ productivity increase, respectively, compared to the control treatment. The BSS and BSS + RSS treatments provided better water productivity, with values of 14.5 and 13.3 kilogram produced for each cubic meter of water applied, respectively. All soil chemical characteristics analyzed were modified when the biochar was incorporated into the soil. The results provide valuable insight that okra growers can embrace the use of the combination BSS+RSS and BSS, providing better yields and lower water use in growing this plant.
\end{abstract}

Keywords: biochar combinations; horticulture; soil fertility; water productivity.

Biocarvão e seu impacto nas propriedades do solo, crescimento e produtividade de plantas de quiabo

\section{Resumo}

A aplicação de biocarvão no solo pode atenuar problemas que dificultam a produção agrícola, como escassez de água e solos com baixa fertilidade. O objetivo desta pesquisa foi avaliar o impacto das combinações de biocarvão de casca de coco seco e lodo de esgoto nas características químicas do solo, crescimento, rendimento e produtividade de água da cultura do quiabo. $O$ experimento foi organizado em blocos casualizados, com 6 tratamentos (CHB + BSS - biocarvão de casca de coco + biocarvão de lodo de esgoto, CHB + RSS - biocarvão de casca de coco + lodo de esgoto bruto, BSS + RSS - biocarvão de lodo de esgoto + lodo de esgoto bruto, CHB - biocarvão de casca de coco, BSS - biocarvão de lodo de esgoto, WB sem biocarvão (controle)). Foram avaliados a altura da planta, número de frutos por planta, produtividade e produtividade de uso da água. Para avaliar o efeito do biocarvão no solo, foram coletadas amostras de solo para determinação das concentrações de $\mathrm{pH}, \mathrm{CEC}, \mathrm{P}, \mathrm{K}, \mathrm{Ca}, \mathrm{Mg}$ após incorporação do biocarvão no solo. Os tratamentos BSS + RSS e BSS proporcionaram melhores resultados nas características de produção e crescimento de quiabo, com um aumento de produtividade de $421,15 \%$ e $419 \%$, respectivamente, em comparação com o tratamento controle. Os tratamentos BSS e BSS + RSS proporcionaram melhores valores de produtividade da água, com valores de 14,5 e 13,3 quilos produzidos para cada metro cúbico de água aplicado, respectivamente. Todas as características químicas do solo analisadas foram modificadas quando o biocarvão foi incorporado ao solo. Os resultados fornecem informações valiosas de que os produtores de quiabo podem adotar o uso da combinação BSS + RSS e BSS, proporcionando melhores rendimentos e menor uso de água no cultivo desta planta.

Palavras-chave: combinações de biocarvão; horticultura; produtividade da água; fertilidade do solo. 


\section{Introduction}

Okra (Abelmoschus esculentus L. Moench) is a crop that can be grown in several regions that have mainly tropical and subtropical climates (EMUH et al., 2006). It has economic importance (FARIAS et al., 2019), reaching in 2017 the value of the ton that varies from US $\$$ 236.8 (Mexico) to US \$3870.6 (Fiji) worldwide (FAOSTAT, 2017). Okra has several benefits for human consumption, being a good source of carbohydrates, proteins, fats, minerals and vitamins, which aroused interest in growing this vegetable on a large scale (JAIN et al., 2012; SINDHU; PURI, 2016). In order to increase the productivity of crops such as okra in the tropics, inorganic fertilizers were encouraged to be used to improve the low fertility of soils belonging to these locations (ADEKIYA; AGBEDE, 2009), however, these fertilizers have high value (AGBEDE et al., 2008) which makes it necessary to find alternative sources such as biochar to provide this improvement in the soil and increase crop productivity.

The use of biochar as a soil conditioner has been encouraged due to its potential to improve soil structure, chemical characteristics (DOWNIE et al., 2009) and plant growth (GONZAGA et al., 2017; 2018; 2019). Biochar is produced by slow pyrolysis (thermal degradation under limited oxygen conditions) of biomass (PANEQUE et al., 2016). As it is a carbon rich material, its application to soil can significantly increase the soil organic matter content leading to improved soil quality (DOWNIE, 2009; LIU et al., 2014).

Laboratory and field-scale studies have shown that biochar assists in soil water availability and maintenance (AGEGNEHU et al., 2016) and nutrients (AGEGNEHU et al., 2016; PANDIAN et al., 2016; SMITH, 2016), promoting the development of important plant parts such as the roots (ABIVEN et al., 2015; MADARI et al., 2017; OBIA et al., 2016), it also provides better conditions for the development of important soil microorganisms (SHENG; ZHU, 2018; ULYETT et al., 2014). These parameters help to stimulate plant growth, ultimately generating better crop yields (NAIR et al., 2017; NOVAK et al., 2016).

Due to the great variability of the available biomass, different types of biochar can be obtained and, for this reason, their effect on soil properties and agricultural production is also very variable (BORCHARD et al., 2014; JEFFERY et al., 2015). Therefore, a prior assessment of each type of biochar is necessary, as well as its effect on the soil and plants, in order to identify which raw material is ideal to guarantee the highest productivity.

The study of the impact of biochar on agricultural production has been studied by many researchers (PETTER et al., 2012; KRASKA et al., 2016; WIN et al., 2019), mainly regarding irrigation water use productivity, aiming to mitigate problems with lack of water and low fertility soils (AKHTAR et al., 2014; AGBNA et al., 2017).

Most biochar studies are carried out under greenhouse and vessel conditions. Little has been studied about combinations of biochar and different raw materials and how this addition affects the productivity of water use in field crops. In addition, few studies have been carried out with okra plants in relation to the application of biochar in the soil. Therefore, we evaluated the impact of biochar combinations of dry coconut shell and sewage sludge on the chemical characteristics of the soil, development, yield and water productivity of the okra culture.

\section{Material and Methods}

Experimental site

The experiment was conducted in the field at the experimental station of the Federal University of Sergipe (UFS), located in the municipality of São Cristovão / SE, Northeast Brazil (about $10^{\circ} 55$ '46 " S; 37 06' 13" W). The local climate according to Köppen's classification is As type, ie rainy tropical with dry summer and annual rainfall around $1200 \mathrm{~mm}$, concentrated between April to September months. The soil is classified as Yellow Red Argisol according to Santos et al. (2013), Ultisol, according to Soil Survey Staff (2014), and presented the following physicochemical characteristics: $\mathrm{pH}=4.64 ; \mathrm{P}=$ $2.82 \mathrm{mg} \mathrm{dm}{ }^{-3} ; \mathrm{K}=0.65 \mathrm{mmol} \mathrm{dm}{ }^{-3} ; \mathrm{Ca}^{2+}+\mathrm{Mg}^{2+}=$ $0.73 \mathrm{mmol} \mathrm{dm}^{-3} ; \mathrm{Al}^{3+}=0.45 \mathrm{mmol} \mathrm{dm}^{-3}$, effective cation exchange capacity (CEC) $=1.83 \mathrm{mmol} \mathrm{dm}^{-3}$ and effective base saturation $(\mathrm{V})=75.40 \%$. Physical properties were: Sand: $71.57 \%$, Silt: $13.43 \%$, Clay: $15 \%$. The sample was collected in the $0-20 \mathrm{~cm}$ depth layer.

\section{Experimental set up}

The experiment was arranged in randomized blocks, with 6 treatments (CHB+BSS combination of coconut husk biochar and biochar 
of sewage sludge, CHB+RSS- combination of coconut husk biochar and raw sewage sludge, BSS+RSS - combination of biochar of sewage sludge and raw sewage sludge, $\mathrm{CHB}$ - coconut husk biochar, BSS - biochar of sewage sludge, WB - without biochar (control)) and four replicates. The blends were made in the ratio of $1: 1(\mathrm{v}: \mathrm{v})$. The equivalent of the $30 \mathrm{tha}^{-1}$ dose of each biochar and combinations was incorporated at a depth of $5 \mathrm{~cm}$ in soil. The experimental unit consisted of three plants. The biochar was applied and incorporated manually into the soil, with the aid of a shovel, 30 days before sowing. The sowing of the okra cultivar Santa Cruz was carried out, with 3 seeds per hole, with spacing between plants of $0.30 \mathrm{~m}$, and the thinning was performed after emergence. The weeds were removed weekly by hand with the aid of a hoe. The cultivation was carried out between June and July 2016.

\section{Production, chemical characterization, and} feedstock of biochar

Biochar was produced in a furnace adapted and produced at the Federal University of Sergipe using a model developed by $|B|$ (International Biochar Initiative), the TLUD (Top Lid Updraft). Coconut residue (dry coconut husk) and sewage sludge collected at a sewage treatment plant were used as feedstock. The biomass accumulated in the inner chamber of the TLUD furnace was transformed into biochar by slow pyrolysis which lasted approximately 40 minutes for the coconut husk and 2 to 3 hours for the sewage sludge at temperatures ranging from $350-450{ }^{\circ} \mathrm{C}$ in the internal compartment and around 650 to $700{ }^{\circ} \mathrm{C}$ in the outer compartment. The biochar was submitted to laboratory analysis where the chemical characterization followed the methodology used in the determination of soil fertility (Silva, 2009). The characteristics of biochar are shown in Table 1.

Table 1. Characteristics of biochar's.

\begin{tabular}{lcccccc}
\hline & $\mathrm{pH}$ & $\mathrm{EC}$ & $\mathrm{N}$ & $\mathrm{P}$ & $\mathrm{K}$ & $\mathrm{C}$ \\
\cline { 2 - 7 } & $1: 2.5$ & $\mathrm{mS} \mathrm{m}^{-1}$ & \multicolumn{2}{c}{$\%$} & \\
\hline CHB & 10.55 & 3.14 & 9.93 & 0.02 & 1.6 & 60.47 \\
BSS & 7.28 & 10.39 & 16.13 & 1.06 & 3.25 & 34.04 \\
\hline
\end{tabular}

EC - electrical conductivity, CHB - coconut husk biochar, BSS - biochar of sewage sludge.

\section{Crop evapotranspiration and irrigation}

Irrigation was done based on crop evapotranspiration (ETc), determined according to the product between the reference evapotranspiration $\left(E T_{0}\right)$ by the crop coefficient $(\mathrm{Kc})$. The cultivation coefficients for each phenological phase of the culture were those found by Farias et al. (2016). The reference evapotranspiration was calculated by the Penman-Monteith method (ALLEN et al., 1998). The daily values used to determine $\mathrm{ET}_{0}$ were collected at the local weather station. The irrigation method used was dripping with spacing of $0.30 \mathrm{~m}$ and flow rate of $1.2 \mathrm{~L} \mathrm{~h}^{-1}$, with daily irrigation.

\section{Chemical characteristics of soil}

The chemical characterization of the soil occurred after incorporation of biochar into the soil. Chemical analyses were performed ( $\mathrm{pH}, \mathrm{CEC}$, $\mathrm{P}, \mathrm{K}, \mathrm{Ca}$, and $\mathrm{Mg}$ concentrations), following the methodology proposed by Silva (2009). The $\mathrm{pH}$ values were obtained through the electrochemical measurement of the effective concentration of $\mathrm{H}^{+}$ions in the soil solution, by means of a combined electrode immersed in soil / water suspension in the ratio of 1: 2.5 .

\section{Agronomic variables}

The first harvest occurred at 64 days after sowing (DAS) and the last at 92 DAS, totaling 12 harvests, the same ones being made 3 times a week. In each harvest, the fruits were weighed on an analytical balance to two decimal places. The average yield per plant was obtained by harvesting the fruits per plant and then weighing, using average values according to the number of harvests. The values were converted in kilogram $(\mathrm{kg})$ and the productivity was obtained considering the production of the useful area of each plot with subsequent conversion to $t \mathrm{ha}^{-1}$. The height of the plants was measured using a ruler graduated in centimeters in each experimental plot. The number of fruits per plant accumulated until the end of the harvest was obtained. The water use productivity (WUP) was 
calculated for each treatment, in $\mathrm{kg} \mathrm{m}^{-3}$, according to Payero et al. (2009), as follows:

$$
\text { WUP }=\frac{Y}{E T C}
$$

wherein, $\mathrm{Y}=$ yield $\left(\mathrm{kg} \mathrm{m}^{-2}\right)$, ETc $=$ seasonal crop evapotranspiration $(\mathrm{mm})$.

\section{Data analysis}

Data were analyzed using the $R$ statistical software version 3.6.3 (R CORE TEAM, 2013). The analysis of variance (ANOVA), homogeneity and normality of the data was performed. The data were submitted to the Tukey test for mean comparison $(p \leq 0.05)$.

\section{Results and Discussion}

Biochar combinations on soil chemical properties

The $\mathrm{pH}$ values were significantly influenced $(p \leq 0.05)$ by the different treatments (Table 2). Soil pH increased in all biochar treatments, with a $14.30 \%, 13.4 \%$ and $10.04 \%$ increase in CHB, BSS, CHB + BSS treatments respectively.
The addition of biochar showed significant effect $(p \leq 0.05)$ for $\mathrm{Ca}, \mathrm{Mg}, \mathrm{P}$ and $\mathrm{K}$ parameters (Table 2). Ca content was increased by $216.66 \%$ in BSS treatment. For Mg there was a $311.1 \%$ increase in $\mathrm{CHB}+\mathrm{BSS}$ treatment. $\mathrm{P}$ was high when $\mathrm{CHB}$ treatment was used, increasing $28.48 \%$. There was an increase of $1092.6 \%$ of $\mathrm{K}$ in the $\mathrm{CHB}+\mathrm{BSS}$ treatment.

The values of base sum (SB), cation exchange capacity (ECC) and base saturation (V) were significantly influenced by the different treatments (Table 2). In general all treatments had increment of these parameters when compared to the control treatment. There was a $200 \%$ increase in SB in the CHB + BSS treatment. For the CEC parameter, two treatments stood out: BSS, with an increment of $12.43 \%$ and $\mathrm{CHB}+$ BSS, with an increase of $10.73 \%$. The base saturation was modified by the treatments, however, the largest increase was found in the $\mathrm{CHB}+\mathrm{BSS}$ and $\mathrm{CHB}$ treatments, with an increase of $269.83 \%$ and $269 \%$, respectively.

Table 2. Chemical properties of soil with different biochar and combinations.

\begin{tabular}{ccccccccccc}
\hline \multirow{2}{*}{ Treatments } & $\mathrm{pH}$ & $\mathrm{Ca}$ & $\mathrm{Al}$ & $\mathrm{Mg}$ & $\mathrm{P}$ & $\mathrm{K}$ & $\mathrm{SB}$ & $\mathrm{CEC}$ & $\mathrm{V}$ \\
\cline { 2 - 11 } & -- & \multicolumn{3}{c}{$\mathrm{cmol} \mathrm{dm}^{-3}$} & & \multicolumn{2}{c|}{$\mathrm{mg} \mathrm{dm}^{-3}$} & $\mathrm{cmol} \mathrm{dm}^{-3}$ & $\%$ \\
\cline { 2 - 11 } CHB+BSS & $4.93 \mathrm{a}$ & $0.61 \mathrm{~b}$ & $0.47 \mathrm{bc}$ & $0.37 \mathrm{a}$ & $1.93 \mathrm{e}$ & $96.6 \mathrm{a}$ & $1.23 \mathrm{a}$ & $3.92 \mathrm{a}$ & $31.3 \mathrm{a}$ \\
CHB+RSS & $4.89 \mathrm{ab}$ & $0.49 \mathrm{c}$ & $0.56 \mathrm{a}$ & $0.13 \mathrm{c}$ & $2.07 \mathrm{e}$ & $21.6 \mathrm{c}$ & $0.68 \mathrm{c}$ & $3.49 \mathrm{c}$ & $19.3 \mathrm{c}$ \\
BSS+RSS & $4.89 \mathrm{ab}$ & $0.68 \mathrm{~b}$ & $0.60 \mathrm{a}$ & $0.19 \mathrm{~b}$ & $4.20 \mathrm{c}$ & $8.5 \mathrm{~d}$ & $0.89 \mathrm{~b}$ & $3.69 \mathrm{~b}$ & $24.1 \mathrm{~b}$ \\
CHB & $5.12 \mathrm{a}$ & $0.39 \mathrm{~d}$ & $0.39 \mathrm{c}$ & $0.22 \mathrm{~b}$ & $6.00 \mathrm{a}$ & $44.6 \mathrm{~b}$ & $0.72 \mathrm{c}$ & $2.32 \mathrm{~d}$ & $31.2 \mathrm{a}$ \\
BSS & $5.08 \mathrm{a}$ & $0.95 \mathrm{a}$ & $0.43 \mathrm{c}$ & $\mathrm{nd}$ & $3.74 \mathrm{~d}$ & $10.1 \mathrm{~d}$ & $0.98 \mathrm{~b}$ & $3.98 \mathrm{a}$ & $24.5 \mathrm{~b}$ \\
WB & $4.48 \mathrm{~b}$ & $0.30 \mathrm{~d}$ & $0.65 \mathrm{a}$ & $0.09 \mathrm{c}$ & $4.67 \mathrm{~b}$ & $8.10 \mathrm{~d}$ & $0.41 \mathrm{~d}$ & $3.54 \mathrm{bc}$ & $11.6 \mathrm{c}$ \\
CV (\%) & 3.21 & 6.22 & 6.84 & 9.57 & 3.16 & 6.19 & 4.94 & 1.94 & 9.61 \\
\hline
\end{tabular}

SB - sum of bases; CEC - cation exchange capacity; $V$ - base saturation. Values followed by the same letter within a column are not significantly different at $p \leq 0.05$ level based on Tukey test.

The treatments with coconut shell, sewage sludge and their combination, provided an increase in soil $\mathrm{pH}$ (Table 2), promoting an alkaline behavior. Large differences in soil $\mathrm{pH}$ can be seen depending on the raw material that is used for biochar production. The alkalinity of biochar is an important factor in controlling its liming effect (YUAN; XU, 2011). Table 1 shows that the biochar CHB and BSS feedstock have a high $\mathrm{pH}$ value, which probably led to their increase in soil. The increase in $\mathrm{pH}$ is consistent with other studies found in the literature (SHACKLEY et al., 2012; UZOMA et al., 2011). The modification of $\mathrm{pH}$ in the soil is dependent on the raw material that the biochar was made, for this reason it is noted that each biochar and combinations presented different values.

Ca levels were modified in the soil (Table 2), so adding biochar to the soil may increase the calcium available to the plants. This fact is related to the negative charges present in biochar that attract positively charged ions like $\mathrm{Ca}$, and make it available to plants (ABDUL; ABDUL, 2017). The biochar can then be used to increase the calcium content available to plants. Some researchers found positive responses to the Ca parameter in 
the soil (SACKETT et al., 2015; PAVLÍKOVÁ et al., 2014).

$\mathrm{Mg}$ in the soil was modified by incorporating biochar (Table 2). The combination $\mathrm{CHB}+\mathrm{BSS}, \mathrm{BSS}+\mathrm{RSS}$ and CHB promoted increase of this nutrient. This is important for regions where predominant tropical and subtropical soils are generally $\mathrm{Mg}$ deficient due to extensive leaching (MASUD et al., 2014). Other researchers found similar results and attributed this event to the raw material used for biochar production (MARTINSEN et al., 2015; CARTER et al., 2013).

The incorporation of CHB increased the level of $\mathrm{P}$ in the soil (Table 2). This may have been due to the fact that the increase in $\mathrm{pH}$ provided by the biochar may have improved the availability of $P$ that was already present in the soil, since the $P$ content in this biochar is low (Table 1). Gonzaga et al. (2017) observed the same effect as biosolid derived biochar. Logically this is related to the biochar raw material and its efficiency in the adsorption and availability of this nutrient to plants. According to Chintala et al. (2014) and Zhang et al. (2016), biochar's ability to increase $P$ retention in soils is quite variable, and this variation is due to $P$ concentration in the soil solution. The $\mathrm{CHB}+\mathrm{BSS}$ combination increased the soil $\mathrm{K}$ level. Some studies have shown that increasing $\mathrm{K}$ by adding biochar to soil can improve crop development (ORAM et al., 2014; ABU ZIED AMIN, 2016). Robertson et al. (2012), found an increase in soil $\mathrm{K}$ content when biochar was used in a greenhouse experiment. This proves that biochar can be an important source of this nutrient as $\mathrm{K}$ is linked to much of the development of agricultural crops.
Soil CEC was modified through treatments, and the highest value was found in $\mathrm{CHB}+\mathrm{BSS}$ and BSS treatments. The increase in CEC is related to surface area, negative surface charge and biochar charge density (LI et al., 2018). In addition, there is the presence of oxygenated functional groups on the biochar surface that may influence the increase of soil CEC (GLASER et al., 2003; SOHI et al., 2010). Increase in CEC has been found in other studies (MARTINSEN et al., 2015; HILIOTI et al., 2017; CORNELISSEN et al., 2018; HAILEGNAW et al., 2019). There was an improvement in soil $V$ values in the use of biochar, with an increase in all treatments, with the highest values found in the $\mathrm{CHB}+\mathrm{BSS}$ and $\mathrm{CHB}$ treatments. This positive change in $\mathrm{V}$ values can be explained by the increase in $\mathrm{pH}$ and soil cations $\left(\mathrm{Ca}^{2+}, \mathrm{Mg}^{2+}\right.$ and $\left.\mathrm{K}^{+}\right)$, and it is also related to changes in soil CEC and type of residue (CARMO et al., 2016).

\section{Growth and water productivity of okra}

The results of okra growth parameters can be seen in figures 1 and 2. Growth variables, plant height $(\mathrm{cm})$, fruits per plant and yield ( $\mathrm{t}$ ha $\left.{ }^{1}\right)$ were significantly influenced $(p \leq 0.05)$. For the plant height variable there was an increase of $60.58 \%$ and $55.4 \%$ in the BSS and BSS + RSS treatments respectively (Figure 1), in comparison to control treatment. The number of fruits per plant increased in BSS + RSS and BSS treatments, causing an increase of $669.7 \%$ and $581.8 \%$ respectively, when compared to the control treatment (Figure 1).

Figure 1. Effect of the combinations and type of biochar on average plant height $(\mathrm{cm})$ and fruits per plant of okra. Different letters in bar of each treatment represents significant differences between various treatments following ANOVA (Tukey test, $p \leq 0.05$ ).
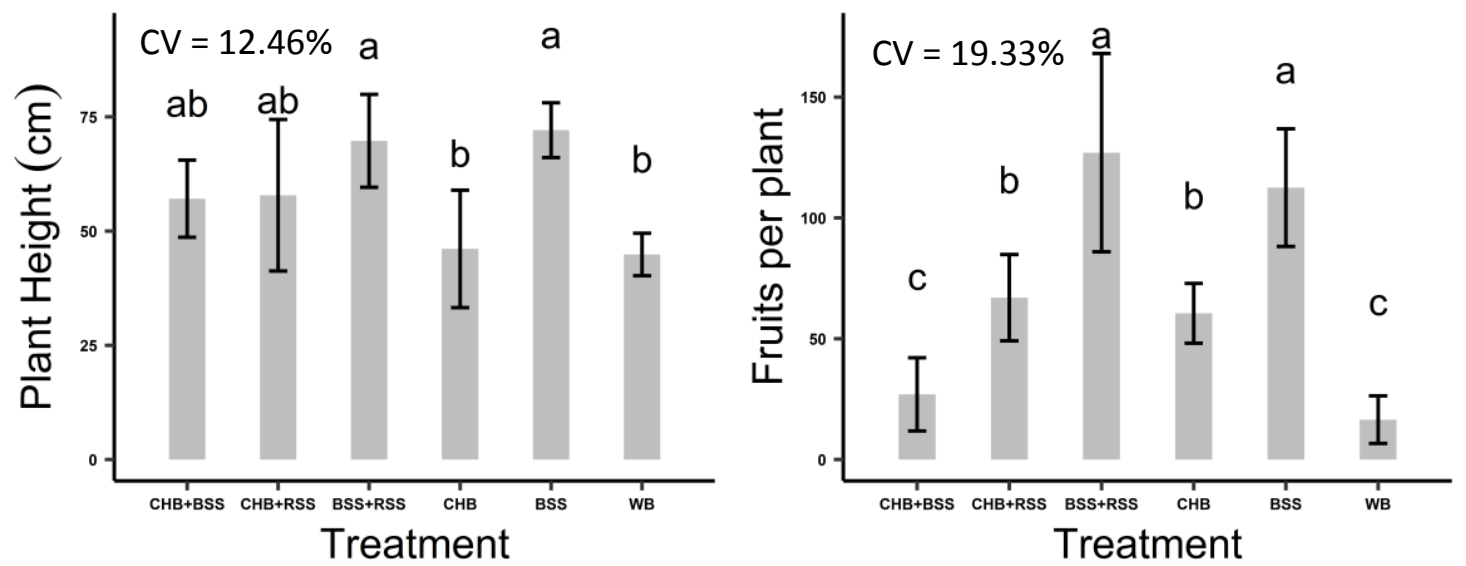
The highest yields were found in the BSS + RSS and BSS treatments with an increment of $421.15 \%$ and $419 \%$, corresponding to 13.00 and 12.92 tonnes more than the control treatment (Figure 2). The best results of water use productivity were found in the BSS and BSS + RSS treatments, with values of 14.5 and $13.3 \mathrm{~kg}$ produced for each cubic meter of water applied, respectively (Figure 2 ).

Figure 2. Effect of the combinations and type of biochar on productivity and water productivity of okra. Different letters in bar of each treatment represents significant differences between various treatments following ANOVA (Tukey test, $p \leq 0.05$ ).

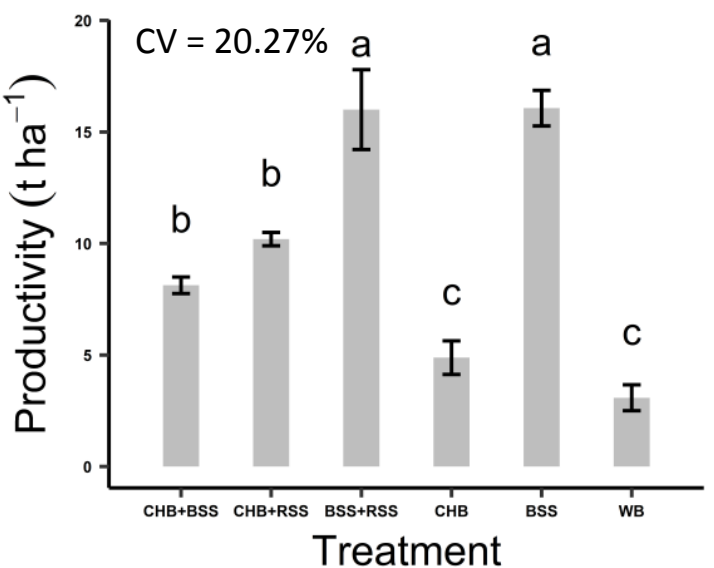

The different biochar combinations promoted changes in the plant height and number of fruits per plant. Jeffery et al. (2011), showed that when there is an increase in soil $\mathrm{pH}$, there is also an increase in the availability of nutrients, which may explain the effect of adding this combination of biochar. This shows that in acidic soils when there is an increase in soil $\mathrm{pH}$, there is also an increase in the availability of the most essential nutrients, except cationic micronutrients, and this is because each nutrient has an ideal $\mathrm{pH}$ range that maximizes its absorption by plants. Wong et al. (2009), showed that when making changes such as applying organic materials to the soil there may be an improvement in soil characteristics, which implies improved plant development.

The addition of BSS+RSS and BSS significantly improved okra productivity and consequently water use productivity. It is observed that the same treatments showed the best numbers of fruits and plant height, which reflected in the final productivity, that is, there was an increase in productivity with less water use. This is important for regions where water resources are scarce as producers can use these types of biochar to improve soil chemical characteristics and achieve higher yields without using more water. The cause of this improvement in water use productivity may be due to changes

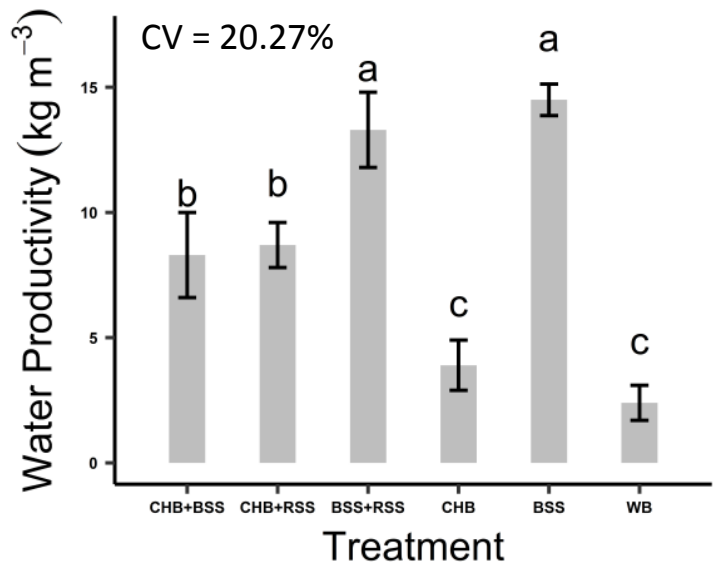

in total porosity and soil density, which may have improved soil hydraulic conductivity and its ability to retain water and make it available to plants (FALOYE et al., 2019; AJAYI; RAINER, 2017; SUN et al., 2013).

The present study demonstrated that okra increases its productive characteristics and optimizes the use of water when subjected to biochar application to the soil. The application of different types of biochar promoted changes in the chemical parameters of the soil which increased okra productivity. BSS + RSS and BSS treatments revealed a significant increase in okra productivity and water productivity. It is possible to verify the influence of these treatments on the okra plant and how it behaved during its development. Therefore, this research can serve as a basis for other locations where resources are scarce, thus contributing to increase the productivity of this crop in the most diverse regions of the world.

\section{Conclusions}

The results found in this research indicated that the use of biochar incorporated in the soil may be beneficial for increasing okra productivity, optimizing water use and improving soil chemical characteristics. The BSS + RSS and BSS treatments provided the best results of okra production parameters, showing that these types 
of biochar can be used in okra production, and that the biochar raw material is decisive in deciding whether or not to use it. Soil chemical parameters have been modified as a function of the raw material used in the production of biochar, which may promote the reduction of the application of chemical fertilizers to the soil by farmers.

\section{Acknowledgement}

The authors thank the experimental farm of the Federal University of Sergipe and the National Council for Technological Development (CNPq) for granting scholarship to the first author.

\section{References}

ABDUL, R. N. F.; ABDUL, R. N. S. The effect of biochar application on nutrient availability of soil planted with MR219. Journal of Microbial and Biochemical Technology, v.9, p.583-586, 2017.

ABIVEN, S.; HUND, A.; MARTINSEN, V.; CORNELISSEN, G. Biochar amendment increases maize root surface areas and branching: a shovelomics study in Zambia. Plant and Soil, v.395, n.1, p.45-55, 2015. https://doi.org/10.1007/s11104-015-2533-2

ABU ZIED AMIN, A. E. E. Impact of corn cob biochar on potassium status and wheat growth in a calcareous sandy soil. Communications in Soil Science and Plant Analysis, v.47, n.17, p.20262033, 2016. https://doi.org/10.1080/00103624.2016.1225081

ADEKIYA, A. O.; AGBEDE, T. M. Growth and yield of tomato (Lycopersicon esculentum Mill) as influenced by poultry manure and NPK fertilizer. Emirates Journal of Food and Agriculture, $\quad 2009$. https://doi.org/10.9755/ejfa.v21i1.5154

AGBeDE, T. M.; OJENIYI, S. O.; ADEYEMO, A. J. Effect of poultry manure on soil physical and chemical properties, growth and grain yield of sorghum in southwest, Nigeria. AmericanEurasian Journal of Sustainable Agriculture, v.2, n.1, p.72-77, 2008.

AGBNA, G. H.; DONGLI, S.; ZHIPENG, L.; ELSHAIKH, N. A.; GUANGCHENG, S.; TIMM, L. C. Effects of deficit irrigation and biochar addition on the growth, yield, and quality of tomato. Scientia Horticulturae, v.222, p.90-101, 2017.

https://doi.org/10.1016/j.scienta.2017.05.004

AGEGNEHU, G.; BASS, A. M.; NELSON, P. N.; BIRD, $M$. I. Benefits of biochar, compost and biocharcompost for soil quality, maize yield and greenhouse gas emissions in a tropical agricultural soil. Science of the Total Environment, v.543, p.295-306, 2016. https://doi.org/10.1016/j.scitotenv.2015.11.054

AJAYI, A. E.; RAINER, H. O. R. N. Biochar-induced changes in soil resilience: effects of soil texture and biochar dosage. Pedosphere, v.27, n.2, p.236-247, 2017. https://doi.org/10.1016/S1002$\underline{0160(17) 60313-8}$

AKHTAR, S. S.; LI, G.; ANDERSEN, M. N.; LIU, F. Biochar enhances yield and quality of tomato under reduced irrigation. Agricultural Water Management, v. 138, p.37-44, 2014. https://doi.org/10.1016/i.agwat.2014.02.016

ALLEN, R. G.; PEREIRA, L. S.; RAES, D.; SMITH, M. Crop evapotranspiration-Guidelines for computing crop water requirements-FAO Irrigation and drainage paper 56. Fao, Rome, v.300, n.9, D05109, 1998.

BORCHARD, N.; SIEMEN, J.; LADD, B.; MÖLLER, A.; AMELUNG, W. Application of biochars to sandy and silty soil failed to increase maize yield under common agricultural practice. Soil Till. Res., v.144, p.184-194, 2014. https://doi.org/10.1016/j.still.2014.07.016

CARMO, D. L. D.; LIMA, L. B. D.; SILVA, C. A. Soil fertility and electrical conductivity affected by organic waste rates and nutrient inputs. Revista Brasileira de Ciência do Solo, v.40, 2016. https://doi.org/10.1590/18069657rbcs20150152

CARTER, S.; SHACKLEY, S.; SOHI, S.; SUY, T.B.; HAEFELE, S. The impact of biochar application on soil properties and plant growth of pot grown lettuce (Lactuca sativa) and cabbage (Brassica chinensis). Agronomy, v.3, n.2, p.404-418, 2013. https://doi.org/10.3390/agronomy3020404

CHINTALA, R.; MOLLINEDO, J.; SCHUMACHER, T. E.; MALO, D. D.; JULSON, J. L. Effect of biochar on chemical properties of acidic soil. Archives of 
Agronomy and Soil Science, v.60, n.3, p.393-404, 2014.

https://doi.org/10.1080/03650340.2013.789870

CORNELISSEN, G.; NURIDA, N. L.; HALE, S. E.; MARTINSEN, V.; SILVANI, L.; MULDER, J. Fading positive effect of biochar on crop yield and soil acidity during five growth seasons in an Indonesian Ultisol. Science of the Total Environment, v.634, p.561-568, 2018. https://doi.org/10.1016/j.scitotenv.2018.03.380

DOWNIE, A.; CROSKY, A.; MUNROE, P. Physical Properties of Biochar. In: LEHMANN, J.; JOSEPH, S (ed.). Biochar for enviromental management: Science and Technology. Londres: Earthscan, 2009. 416p.

EMUH, F. N.; OFUOKU, A. E.; OYEFIA, E. Effect of intercropping okra (Hibiscus esclentus) with pumpkin (Curcubita maxima Dutch ex Lam) on some growth parameters and economic yield of maize (Zea mays) and maximization of land use in a fadama soil. Research Journal of Biological Sciences, v.1, n.1-4, p.50-54, 2006.

FALOYE, O. T.; ALATISE, M. O.; AJAYI, A. E.; EWULO, B. S. Effects of biochar and inorganic fertiliser applications on growth, yield and water use efficiency of maize under deficit irrigation. Agricultural Water Management, v.217, p.165-178, 2019. https://doi.org/10.1016/j.agwat.2019.02.044

FAOSTAT. (2017). http://www.fao.org/faostat/en/\#data/PP.

FARIAS, D. B. S.; SILVA, P. S. O.; LUCAS, A. A. T.; FREITAS, M. I.; JESUS SANTOS, T.; FONTES, P. T. N.; OLIVEIRA JÚNIOR, L. F. G. Physiological and productive parameters of the okra under irrigation levels. Scientia Horticulturae, v.252, p.1-6, 2019.

https://doi.org/10.1016/j.scienta.2019.02.066

FARIAS, D.B.S.; LUCAS, A.A.T.; NASCIMENTO, L.F.A.; SÁ FILHO, J.C.F.; LIMA., I.S. Construction, installation and calibration of water table lisymeter for conditions of state Sergipe. Concepción. In: CRHIAM-INOVAGRI INTERNATIONAL MEETING. Proceedings [...]. 2016. p. 811-817.
GLASER, B.; GUGGENBERGER G.; ZECH, W.; RUIVO, M.L. Soil organic matter stability in Amazon Dark Earth. In: LEHMANN, J. et al. (eds.). Amazonian dark earths: origin, properties, management. Dodrecht: Kluwer Academic Publishers, p.141-158, 2003. https://doi.org/10.1007/1-4020-2597-1 8

GONZAGA, M. I. S.; MACKOWIAK, C. L.; COMERFORD, N. B.; VEIGA MOLINE, E. F.; SHIRLEY, J. P.; GUIMARAES, D. V. Pyrolysis methods impact biosolids-derived biochar composition, maize growth and nutrition. Soil and Tillage Research, v.165, p.59-65, 2017. https://doi.org/10.1016/j.still.2016.07.009

GONZAGA, M. I. S.; MACKOWIAK, C.; ALMEIDA, A. Q. D.; JÚNIOR, C. Sewage sludge derived biochar and its effect on the growth and morphological traits of Eucalyptus grandis w. hill ex maiden seedlings. Ciência Florestal, v.28, n.2, p.687-695, 2018. https://doi.org/10.5902/1980509832067

GONZAGA, M. I. S.; SOUZA, D. C. F. D.; ALMEIDA, A. Q. D.; MACKOWIAK, C.; LIMA, I. D. S.; SANTOS, J. C. D. J.; ANDRADE, R. S. D. Nitrogen and phosphorus uptake efficiency in Indian mustard cultivated during three growth cycles in a copper contaminated soil treated with biochar. Ciência Rural, v.49, n.1, 2019. https://doi.org/10.1590/0103-8478cr20170592

HAILEGNAW, N. S.; MERCL, F.; PRAČKE, K.; SZÁKOVÁ, J.; TLUSTOŠ, P. Mutual relationships of biochar and soil pH, CEC, and exchangeable base cations in a model laboratory experiment. Journal of Soils and Sediments, v.19, n.5, p.2405-2416, 2019. https://doi.org/10.1007/s11368-019-02264-z

HILIOTI, Z.; MICHAILOF, C. M.; VALASIADIS, D.; ILIOPOULOU, E. F.; KOIDOU, V.; LAPPAS, A. A. Characterization of castor plant-derived biochars and their effects as soil amendments on seedlings. Biomass and bioenergy, v.105, p.96106,

2017. https://doi.org/10.1016/j.biombioe.2017.06.022

JAIN, N.; JAIN, R.; JAIN, V.; JAIN, S. A review on: Abelmoschus esculentus. Pharmacia, v.1, n.3, p.84-89, 2012. 
JEFFERY, S.; MEINDERS, M.B.J.; STOOF, C.R.; BEZEMER, T.M.; VAN DE VOORDE, T.F.J.; MOMMER, L.; VAN GROENIGEN, J.W. Biochar application does not improve the soil hydrological function of a sandy soil. Geoderma, v.251-252, p.47-54, 2015. https://doi.org/10.1016/j.geoderma.2015.03.022

JEFFERY, S.; VERHEIJEN, F. G.; VAN DER VELDE, M.; BASTOS, A. C. A quantitative review of the effects of biochar application to soils on crop productivity using meta-analysis. Agriculture, ecosystems \& environment, v.144, n.1, p.175187, 2011. https://doi.org/10.1016/j.agee.2011.08.015

KRASKA, P.; OLESZCZUK, P.; ANDRUSZCZAK, S.; KWIECIŃSKA-POPPE, E.; RÓŻYŁO, K.; PAŁYS, E.; MICHAŁOJĆ, Z. Effect of various biochar rates on winter rye yield and the concentration of available nutrients in the soil. Plant, Soil and Environment, v.62, n.11, p.483-489, 2016. https://doi.org/10.17221/94/2016-PSE

LEHMANN, J.; JOSEPH, S. Biochar for environmental management: science, technology and implementation. Routledge, 2015.

LI, Z.; DELVAUX, B.; YANS, J.; DUFOUR, N.; HOUBEN, D.; CORNELIS, J. T. Phytolith-rich biochar increases cotton biomass and siliconmineralomass in a highly weathered soil. Journal of Plant Nutrition and Soil Science, v.181, n.4, p.537-46, Aug. 2018. https://doi.org/10.1002/jpln.201800031

LIU, Z.; CHEN, X.; JING, Y.; LI, Q.; ZHANG, J.; HUANG, Q. Effects of biochar amendment on rapeseed and sweet potato yields and water stable aggregate in upland red soil. Catena, v.123, p.45-51, 2014. https://doi.org/10.1016/i.catena.2014.07.005

MARTINSEN, V.; ALLING, V.; NURIDA, N.L.; MULDER, J.; HALE, S.E.; RITZ, C.; RUTHERFORD, W.; HEIKENS, A.; BREEDVELD, G.D.; GERARD, C.; CORNELISSEN, G. pH effects of the addition of three biochars to acidic Indonesian mineral soils. Journal of Soil Science and Plant Nutrition, v.61, n.5, p.821-834, 2015. https://doi.org/10.1080/00380768.2015.1052985
MASUD, M. M.; JIU-YU, L. I.; REN-KOU, X. U. Use of alkaline slag and crop residue biochars to promote base saturation and reduce acidity of an acidic Ultisol. Pedosphere, v.24, n.6, p.791-798, $2014 . \quad$ https://doi.org/10.1016/S10020160(14)60066-7

NAIR, V. D.; NAIR, P. K.; DARI, B.; FREITAS, A. M.; CHATTERJEE, N.; PINHEIRO, F. M. Biochar in the agroecosystem-climate-change-sustainability nexus. Frontiers in Plant Science, v.8, n.2051, 2017. https://doi.org/10.3389/fpls.2017.02051

NOVAK, J. M.; IPPOLITO, J. A.; LENTZ, R. D.; SPOKAS, K. A.; BOLSTER, C. H.; SISTANI, K.; JOHNSON, M. G. Soil health, crop productivity, microbial transport, and mine spoil response to biochars. BioEnergy Research, v.9, n.2, p.454464, 2016. https://doi.org/10.1007/s12155-016$\underline{9720-8}$

OBIA, A.; MULDER, J.; MARTINSEN, V.; CORNELISSEN, G.; BØRRESEN, T. In situ effects of biochar on aggregation, water retention and porosity in light-textured tropical soils. Soil Tillage Research, v.155, p.35-44, 2016. https://doi.org/10.1016/i.still.2015.08.002

ORAM, N. J.; VAN DE VOORDE, T. F.; OUWEHAND, G. J.; BEZEMER, T. M.; MOMMER, L.; JEFFERY, S.; VAN GROENIGEN, J. W. Soil amendment with biochar increases the competitive ability of legumes via increased potassium availability. Agriculture, Ecosystems \& Environment, v.191, p.92-98, 2014. https://doi.org/10.1016/j.agee.2014.03.031

PANDIAN, K.; SUBRAMANIAYAN, P.; GNASEKARAN, P.; CHITRAPUTHIRAPILLAI, S. Effect of biochar amendment on soil physical, chemical and biological properties and groundnut yield in rainfed Alfisol of semi-arid tropics. Archives of Agronomy and Soil Science, v.62, n.9, p.12931310,

2016. https://doi.org/10.1080/03650340.2016.1139086

PANEQUE, M.; JOSÉ, M.; FRANCO-NAVARRO, J. D.; COLMENERO-FLORES, J. M.; KNICKER, $\mathrm{H}$. Effect of biochar amendment on morphology, productivity and water relations of sunflower plants under non-irrigation conditions. Catena, v.147, p.280-287, 2016. https://doi.org/10.1016/j.catena.2016.07.037 
PAVLÍKOVÁ, D.; ZEMANOVÁ, V.; PROCHÁZKOVÁ, D.; PAVLÍK, M.; SZÁKOVÁ, J.; WILHELMOVÁ, N. The long-term effect of zinc soil contamination on selected free amino acids playing an important role in plant adaptation to stress and senescence. Ecotoxicology and Environmental Safety, v.100, p.166-170, 2014. https://doi.org/10.1016/j.ecoenv.2013.10.028

PAYERO, J. O.; TARKALSON, D. D.; IRMAK, S.; DAVISON, D.; PETERSEN, J. L. Effect of timing of a deficit-irrigation allocation on corn evapotranspiration, yield, water use efficiency and dry mass. Agricultural Water Management, v.96, p.1387-1397, 2009. https://doi.org/10.1016/i.agwat.2009.03.022

PETTER, F.A.; MADARI, B.E.; SILVA, M.A.S.; CARNEIRO, M.A.C.; CARVALHO, M. T.M.; MARIMON JÚNIOR, B.H.; PACHECO, L.P. Soil fertility and upland rice yield after biochar application in the Cerrado. Pesquisa Agropecuária Brasileira, v.47, n.5, p.699-706, $2012 . \quad$ https://doi.org/10.1590/S0100$\underline{204 \times 2012000500010}$

R CORE TEAM. R: A language and environment for statistical computing. 2013. R Foundation for Statistical Computing, Vienna, Austria. Disponível em: http://www.R-project.org/.

ROBERTSON, S. J.; RUTHERFORD, P. M.; LOPEZGUTIERREZ, J. C.; MASSICOTTE, H. B. Biochar enhances seedling growth and alters root symbioses and properties of sub-boreal forest soils. Canadian Journal of Soil Science, v.92, n.2, p.329-340, 2012. https://doi.org/10.4141/cjss2011-066

SACKETT, T. E.; BASILIKO, N.; NOYCE, G. L.; WINSBOROUGH, C.; SCHURMAN, J.; IKEDA, C.; THOMAS, S. C. Soil and greenhouse gas responses to biochar additions in a temperate hardwood forest. Gcb Bioenergy, v.7, n.5, 1062-1074, 2015. https://doi.org/10.1111/gcbb.12211

SANTOS, H. G. et al. Sistema Brasileira de classificação do solo. 3. ed. Brasília: Embrapa Solos. 2013. 353p.

SHACKLEY, S.; SOHI, S.; IBARROLA, R.; HAMMOND, J.; MAŠEK, O.; BROWNSORT, P.; HASZELDINE, S. Biochar as a tool for climate change mitigation and soil management. In:
MEYERS, R. (Ed.). Encyclopedia of sustainability science and technology. New York: Springer: 2012. p.183-205. https://doi.org/10.1007/978-14614-5770-1 6

SHENG, Y.; ZHU, L. Biochar alters microbial community and carbon sequestration potential across different soil $\mathrm{pH}$. Science of the Total Environment, v.622-623, p.1391-1399, 2018.

https://doi.org/10.1016/j.scitotenv.2017.11.337

SILVA, F.C. Manual de análise química de solos, plantas e fertilizantes. Brasília: Embrapa Solos, 2009.

SINDHU, R. K.; PURI, V. Phytochemical, nutritional and pharmacological evidences for Abelmoschus esculentus (L.). J Phytopharmacol, v.5, n.6, p.238-241, 2016.

SMITH, P. Soil carbon sequestration and biochar as negative emission technologies. Global Change Biology, v.22, n.3, p.1315-1324, 2016. https://doi.org/10.1111/gcb.13178

SOHI, S. P.; KRULL, E.; LOPEZ-CAPEL, E.; BOL, R. A review of biochar and its use and function in soil. Advances in Agronomy, v.105, p.47-82, $2010 . \quad$ https://doi.org/10.1016/S00652113(10)05002-9

SOIL SURVEY STAFF. Keys to soil taxonomy. 12. ed. Lincoln, NE: USDA-NRCS, 2014.

SUN, K.; KANG, M.; ZHANG, Z.; JIN, J.; WANG, Z.; PAN, Z.; XING, B. Impact of deashing treatment on biochar structural properties and potential sorption mechanisms of phenanthrene. Environmental Science \& Technology, v. 47, n.20, p.11473-11481, 2013. https://doi.org/10.1021/es4026744

ULYETT, J.; SAKRABANI, R.; KIBBLEWHITE, M.; HANN, M. Impact of biochar addition on water retention, nitrification and carbon dioxide evolution from two sandy loam soils. European Journal of Soil Science, v.65, n.1, p.96-104, 2014. https://doi.org/10.1111/ejss.12081

UZOMA, K. C.; INOUE, M.; ANDRY, H.; FUJIMAKI, H.; ZAHOOR, A.; NISHIHARA, E. Effect of cow manure biochar on maize productivity under sandy soil condition. Soil use and 
management, v.27, n.2, p.205-212, 2011. https://doi.org/10.1111/i.14752743.2011.00340.x

WIN, K.T.; OKAZAKI, K.; OOKAWA, T.; YOKOYAMA, T.; OHWAKI, Y. Influence of rice-husk biochar and Bacillus pumilus strain TUAT- 1 on yield, biomass production, and nutrient uptake in two forage rice genotypes. PloS One, v.14, n.7, 2019. https://doi.org/10.1371/journal.pone.0220236

WONG, V.; DALAL, R.; GREENE, R. Carbon dynamics of sodic and saline soils following gypsum and organic material additions: a laboratory incubation. Applied Soil Ecology, v.41, n.1, p.29-40, 2009. https://doi.org/10.1016/j.apsoil.2008.08.006

YUAN, J. H.; XU, R. K. The amelioration effects of low temperature biochar generated from nine crop residues on an acidic Ultisol. Soil Use and Management, v.27, n.1, p.110-115, 2011. https://doi.org/10.1111/j.14752743.2010.00317.x

ZHANG, H.; CHEN, C.; GRAY, E. M.; BOYD, S. E.; YANG, H.; ZHANG, D. Roles of biochar in improving phosphorus availability in soils: a phosphate adsorbent and a source of available phosphorus. Geoderma, v.276, p.1-6, 2016. https://doi.org/10.1016/i.geoderma.2016.04.020 